\title{
Motivational factors in multilevel marketing business: A confirmatory approach
}

\author{
Sourav Jain ${ }^{a^{*}}$, B.B. Singla ${ }^{\mathrm{b}}$ and Shashi Shashi ${ }^{\mathrm{a}}$
}

${ }^{a}$ Research Scholar, Punjabi University, Patiala, India ${ }^{b}$ Assistant Professor, Punjabi University, Patiala, India

\begin{tabular}{l}
\hline C H R O N I C L E \\
\hline Article history: \\
Received March25, 2015 \\
Received in revised format \\
August62015 \\
Accepted August 92015 \\
Available online \\
August102015 \\
\hline Keywords: \\
Multilevel marketing system \\
Motivation \\
Compensation plans \\
Network marketing \\
Ponzi schemes
\end{tabular}

\begin{abstract}
A B S T R A C T
In the present scenario of high unemployment; Multilevel Marketing (MLM) generates employment for people who have no permanent source of earning. MLM system has emerged as one of the prime alternatives in the current marketing system. India has become a very popular destination of doing MLM business with high potential of growth. MLM system provides lucrative compensation that works as motivation for people to join this business. Motivation for executives of any firm plays a major role in its success. It also leads commitment of employees towards work and responsibilities. An attempt has been made to identify the motivational variables that have the highest level of contribution for joining the MLM system. Most of the MLMcompanies focus on compensation plan or reward system but apart from that a number of variables have been found which motivate the distributors to engage in MLM business. Further, the distributors play a vital role in the growth of the business. In this study, we also propose a motivational model to help MLM companies formulate better strategies in making a large network of people for growth of business.
\end{abstract}

C 2015 Growing Science Ltd. All rights reserved.

\section{Introduction}

The contemporary business system includes manufacturer, distributors, retailers and final customers. Manufacturers make the products and supply to distributors or retailers, which are supplied to the final customers (Singh et al., 2013). With the passage of time, marketing started on playing an important role in business. In marketing, firms usually focus on advertisements by spending a colossal amount of money on promoting their new products in various ways such as TV commercials and newspapers. Thus, the high advertisement cost makes the product costly for customers and decreases the profit of the firm.

\footnotetext{
* Corresponding author. Tel: 9780195189

E-mail address:jainsourav88@gmail.com(S. Jain)

(C) 2015 Growing Science Ltd. All rights reserved. doi: $10.5267 /$ j.msl.2015.8.006
} 


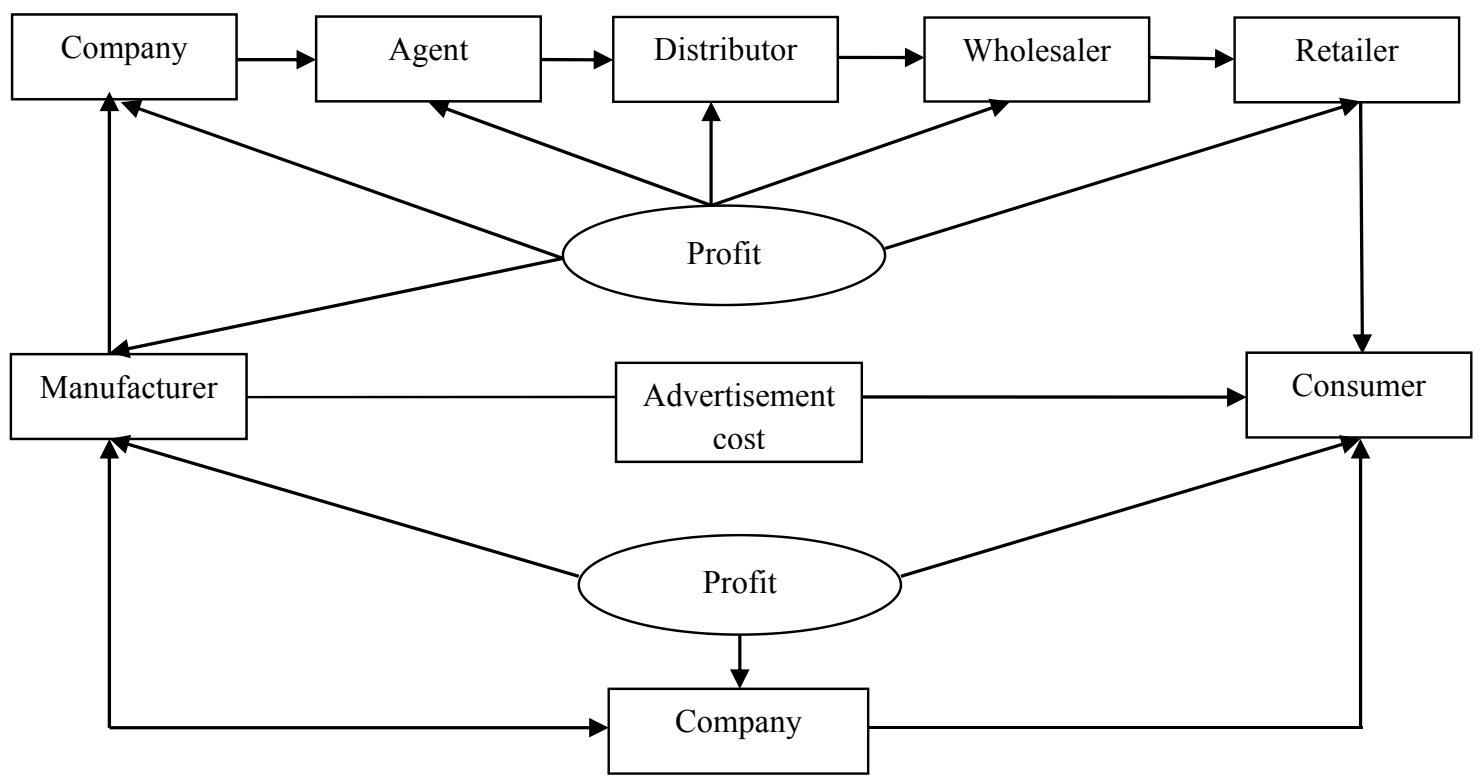

Fig. 1. Direct Selling V/S Contemporary Business System

\subsection{Direct Selling}

In order to abolish the malfunctions of contemporary marketing system and its policies, direct selling concept was developed. Direct selling is also a very old method of doing business. This concept is based on establishing a direct relationship between the customer and producer. It eliminates the role of intermediaries in the distribution channel.

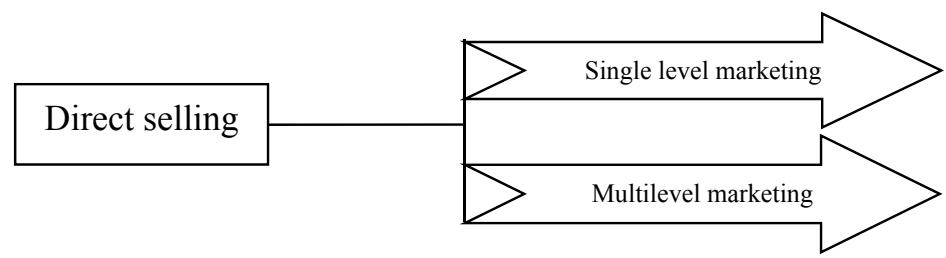

Fig. 2. Types of Direct Selling

\subsection{Types of Direct Selling}

Single Level Marketing: In single level marketing, the salesperson earns the income on the basis of the sales generated by him. He cannot multiply his sales volume by sponsoring other salespersons. Thus, the commission provided to the salespersons is on the basis of their sales performance.

Multilevel Marketing:In this system, the seller becomes distributor of the firm and can recruits other distributors or sales people under his sponsorship (downline). Thus, the uplinedistributor generates bonus and commission on the collectively sales of the group. Downliners help to augment the overall sale, and thus enable the upliners to earn a high commission.

MLM system provides firms an alternative way of promoting products to potential consumers by using relationships. It is the best way to use of human relationships and make a social network across the people. By using Network Marketing or customer referrals, the business entity need not incur advertisement costs. More importantly, the potential customer shows keen interest to buy the products from his acquaintance. 
The origin of MLM is still a matter of confusion among various researchers. According to Pajera (2008) MLM system existed during 1920s to 1930s with Nutrilite or California Perfume Company rebranded as "Avon Product". In the views of Attri (2011) this business concept started in 1940s with the California Vitamin Company. On the other hand, Evert (1994) stated that it originated in the 1960s and even as late as the 1970. In 1959, the employees of Nutrilite Jay Van Andel and Rich DeVos started their own firm called Amway (Dominique, 1993) and also acquired the business of Nutrilite in 1972. Since 1994, Amway is one of the largest business organizations in the MLM industry. In today's MLM business, Avon, Amway, Forever, Modicare, Oriflamme, Tupperware, etc. are the most popular network selling firms.

Microsoft founder Bill Gates says "If I would be given a chance to start all over again, I would choose network marketing".

Nobel Prize winning economist and author Paul Zane Piltzer thinks "Of all the entrepreneurial opportunities available today, one of the most important is direct selling also called network marketing".

Nowadays, MLM is gaining much attention in business circles in the Indian environment. More than 10000 Companies of direct selling are operating in India, whose business turnover is more than 7200 crores in fiscal year 2013-2014 (Indian Direct Selling Association, IDSA). IDSA is an association which regulates the direct selling companies, core issues related to this business and future prospects of the trade in India.In MLM the distributors are compensated not just for their respective sales but the sales generated by the people they recruit. The recruiting is generally done through personal networking as shown in Fig. 3; thus MLM is also called "Network Marketing" (Muncy, 2004).
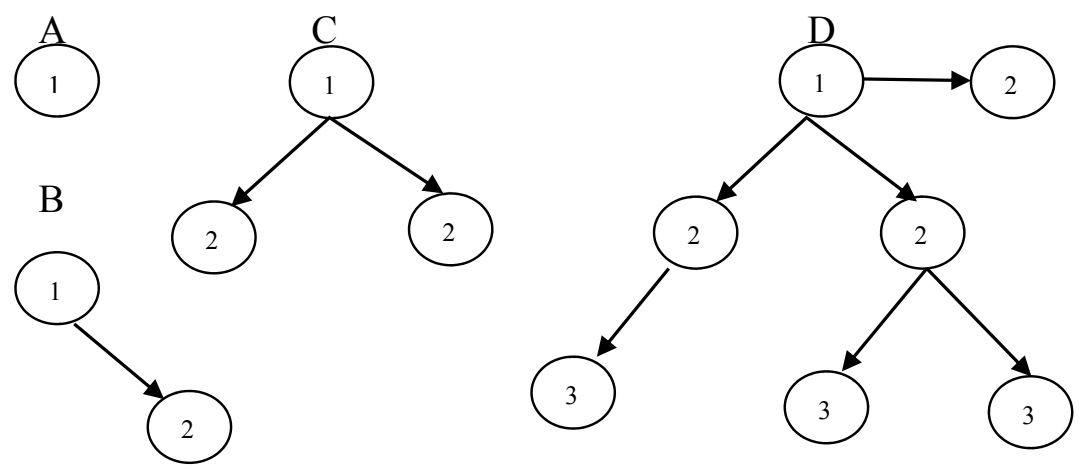

Fig. 3. MLM Network Structure

Most of the researchers have defined MLM is a type of direct selling (Duffy, 2005; Brodie, 2004; Marsh, 2004; Kiew \& Run, 2007). Many researchers have defined MLM like pyramid schemes (Nat \& Wicked, 2002; Maxima, 2013). Some of them described it as network marketing (Oksanes, 1999; Jones, 1995). Though MLM is given various names like Network Marketing, Chain Marketing, (money chain in a negative sense), the basic principle is that a happy consumer brings in more customers for which he is getting an incentive. The compensation plan varies from company to company.

\subsection{MLMCompensation Concept}

Here, an attempt has been made to describe comprehensive MLM concept and distinct types of this system. MLM works on the concept of time leverage and a unique strategy to sell the products to the final customers.

I would rather earn $1 \%$ of 100 people's efforts than $100 \%$ of my own efforts" - John Paul Getty (American Billionaire) 


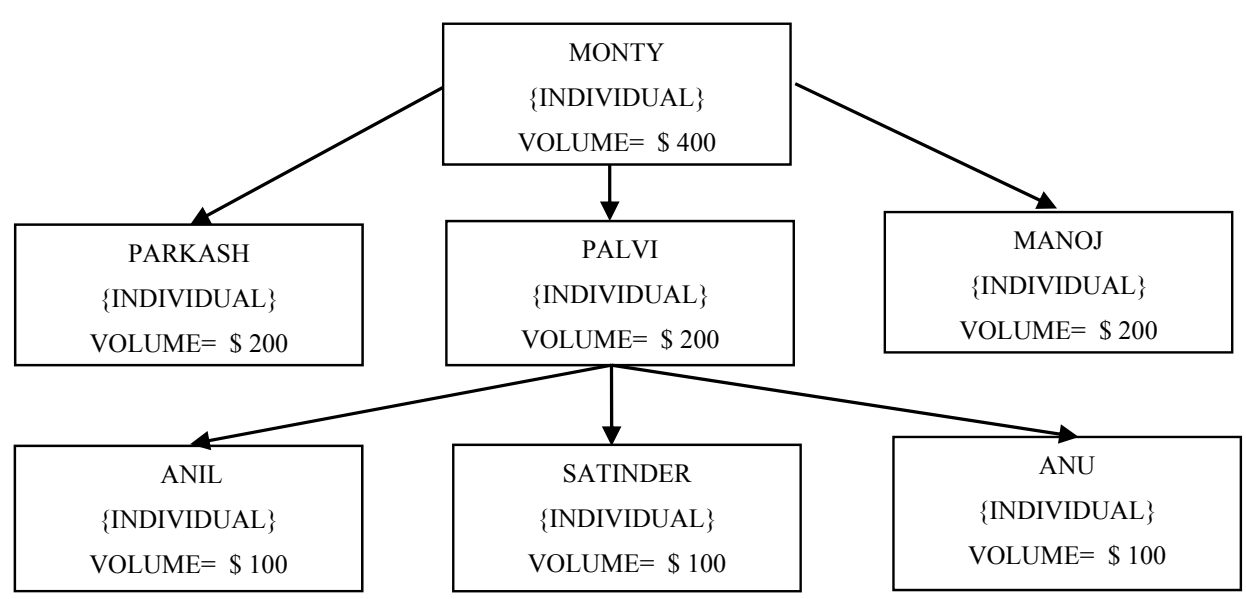

Fig. 4. Compensation Structure

Table 1

Net Compensation Structure

\begin{tabular}{|c|c|c|c|}
\hline Member's Name & Total Volume & commission Rate $\$$ Amount & Net Commission Amount \\
\hline MONTY & US $\$ 1300$ & $10 \%(\mathrm{US} \$ 130)$ & US $\$ 66$ \\
\hline PALVI & US $\$ 500$ & $8 \%($ US \$ 40) & US \$ 28 \\
\hline PARKASH & US $\$ 200$ & $6 \%(\mathrm{US} \$ 12)$ & US \$ 12 \\
\hline MANOJ & US $\$ 200$ & $6 \%$ (US \$ 12) & US \$ 12 \\
\hline ANIL & US $\$ 100$ & $4 \%($ US $\$ 4)$ & US \$ 4 \\
\hline SATINDER & US $\$ 100$ & $4 \%(\mathrm{US} \$ 4)$ & US \$ 4 \\
\hline ANU & US $\$ 100$ & $4 \%$ (US \$ 4 ) & US \$ 4 \\
\hline
\end{tabular}

In this network arena, all the firms have a web based information system where a member can monitor the growth of his down line members, incomes accrued, etc. The visible part of the network is a distribution center (for product based MLM), weekly meetings of members, explanations of business plan, demonstrate products and recognition the achievements, etc.

\section{Literature review}

In MLM system, distributors do not receive a salary, but they received commissions on the sales of the products they sold as well as sold by their downline members whom they recruit. The amount of commissions depends on their group performance. Wang and Chang (1998) demonstrated that Lucrative compensation plan of a firm is the key factor that motivates the distributors to work in an enthusiastic manner. The effective compensation policy of MLM business provides the distributor an opportunity to earn extra money and it also gives the financial satisfaction to distributors (Keun, 2004; Palmatier et al., 2007; Parvi \& Kabir, 2011). Kiewand and Run (2007) reported that financial rewards and product quality allured people to join and stay on in MLM business. Consumers want instantly and convincing solutions to their problems and desire innovative, nutritious and suitable products for consumption. Chaubey and Subramanian (2013) illustrated, the product feel, demonstration, opportunity to test and verify product claims are variables that satisfy the customers. Product quality is considered a prime embolden for repurchasing the products (Devi \& Kalaiselvi, 2014).The MLM system affects its direct customer's willingness to pay through relationship marketing, therefore customers prefer to buy products from acquaintances, relatives, etc. rather than strangers. Oksanes (1999) inferred, distributors tend to create co-operative relationship with other distributors in order to accomplish their goals. This helps in building healthy relationship with co-workers and supervisor that lasts for long term (Parvin \& Kabir, 2011). Hence, the social network as a factor plays an important role in success of business (Marsh, 2004; Palmatier et al., 2007). 
Table 2

Key Motivational Variables

\begin{tabular}{|c|c|}
\hline $\begin{array}{l}\text { Variables that motivate to } \\
\text { join MLM }\end{array}$ & Researchers \\
\hline Compensation: & $\begin{array}{l}\text { Coughlan et al. (1998), Wang \& Cheng (1998), Nat \& Wicked (2002), Keun (2004), Marsh (2004), Keun\& Run } \\
\text { (2007), Chen et al.(2012), Buschgens et al.(2013), Fuji \&Taji (2013), Jumpon et al.(2013) }\end{array}$ \\
\hline Product Quality: & $\begin{array}{l}\text { Cheng(1993), Brodie (2004), Keun\& Run (2007), Goncalves (2008), Constantin (2009), Chen et al. (2012), } \\
\text { Sarada (2012), Jumpon et al.(2013), Jain \&Goyal (2013), Shirani et al.(2014), Devi \&Kalaiselvi (2014) }\end{array}$ \\
\hline Learning: & Akiny (2008), Choudhary (2013), Radmand\&Mukhtaram(2013), Rani \& Kumar (2013) \\
\hline Extra Money: & $\begin{array}{l}\text { :Wang \& Cheng (1998), Keun (2004), Palmatier et al. (2007), Constantin (2009), Chaudhari et al.(2010), Chen } \\
\text { et al. (2012), Qasim\&Sayeed (2012), Choudhary et al. (2013) }\end{array}$ \\
\hline $\begin{array}{l}\text { Corporate Social Responsibility } \\
\text { (CSR): }\end{array}$ & Rattanaphan (2012) \\
\hline Own Hours: & Akiny (2008), Choudhary et al. (2013), Arya \& Arya (2014) \\
\hline Free To Work: & Akiny (2008), Choudhary et al. (2013), Arya \& Arya (2014) \\
\hline Personal Accomplishment: & Miekina (2012), Choudhary et al. (2013) \\
\hline Build Rapport: & Oksanes (1999), Dai Fu (2012) \\
\hline Lavish Lifestyle: & Dai et al. (2011), Spire (2011), Ismail et al. (2012) \\
\hline Leadership: & Sparks (2001), Akiny (2008), Huong (2013), Rani \& Kumar (2013) \\
\hline Financial Security: & Palmatier et al.(2007), Parvin\&Kabir (2011), \\
\hline Be Own Boss: & Choudhary et al. (2013), Arya \& Arya (2014) \\
\hline Entrepreneur: & Choudhary et al. (2013) \\
\hline Recognition: & Chang \& Tseng (2005), Contantin (2009), \\
\hline Company image: & Brodie (2004), Sizovaite\&Pashaloudis (2011), Ismail et al. (2012), Rattanaphan (2012), Reavis (2014) \\
\hline Low Investment: & Zamanian (1986), Albaum\& Peterson (2011), Choudhary et al. (2013) \\
\hline Low Entry Barrier: & Akiny (2008) \\
\hline Company policy: & $\begin{array}{l}\text { Chang \& Tseng (2005), Younus (2006), Parvin\&Kabir (2011), Albaum\& Peterson (2011), Qasim\&Sayeed ( } \\
\text { 2012), Joshi (2013) }\end{array}$ \\
\hline
\end{tabular}

As we earlier discussed, India has become an emerging nation in MLM business. A large number of companies have adopted MLM system but still the people are perplexed to understand the difference between legitimate and illegitimate MLM Company. Some financial scams erupted from time to time hit the reputation of MLM companies and create negative perception towards MLM (Spire, 2011). Most of the people in Australia perceive the network marketing as pyramid scams, aggressive selling techniques, high pressure sales, recruitment policies and ponzi schemes (Kustin \& Jones, 1995). According to Reavis (2014) in ponzi schemes, the compensation is paid by recruiting new members rather than selling the products to consumers. Veena (2014) evinced that lack of sport from up-line members, low income, lack of training, Rigid mindset, pyramid structure and difficult to recognize legal MLM companies are some variables that restrict women to join MLM companies. Thus, The contribution of women in expansion of MLM business is very less as compared to men.

Several studies (Poe, 1999; King \& Robinson, 2000; Hedges, 2001; Kiyosaki, 2004) supported the concept of MLM business and emphasized it as a strong marketing system of $21^{\text {st }}$ century. It also generates extra income for distributors who further can also avail many kinds of benefits.

\section{Conceptual Framework and Gap Analysis}

In this section, the issues related to MLM are reviewed meticulously. The prior studies revealed that this business system has been growing day by day. India has become one of the largest markets in the world in MLM business. The report of IDSA presented that Amway is the market leader in India with $44 \%$ of total market share.In addition to the review of literature, we also conducted the interviews of representatives and top level executives of MLM companies. By taking their views into consideration, we formulated a conceptual framework to depict the motivational factors that have the highest level of contribution in the expansion of MLM business.As we already discussed, many researchers defined MLM in their own style and termed it in a different manner. Although the whole concept is same and it revolves around two sided theory of recruiting and selling. According to Reavis (2014) majority of the people have a negative perception towards MLM because of frequently occurred financial scams that are also called Ponzi schemes. Albaum and Peterson, (2011) described the attributes of legal MLM and explored that it is based on selling the products or services rather than only recruiting new members. 
Cheng (1993), Brodie (2004), Keun \& Run (2007), Goncalves (2008) and Constantin (2009) observed product quality as a major factor that influences the perception of the customer. According to Akiny (2008) there is a low entry barrier because people can join Network Marketing organization with irrespective of their demographic profile. Besides it, researchers covered various issues regarding MLM as: Extra money can be earned through good Compensation plan (Coughlan et al., 1998; Wang \& Cheng, 1998; Nat \& Wicked, 2002) transformational leadership (Sparks \& Schenk, 2006) and entrepreneurial motivation (Kuntze, 2001).MLM system has appeared as one of the most successful marketing systems in the past several decades (Sparks \& Schenk, 2001), still a few researchers conducted empirical studies in this area and also ignored some key motivational variables that persuade people to join MLM business. As shown in Fig. 5. Motivation also leads commitment towards work responsibilities and contributes in business' growth.

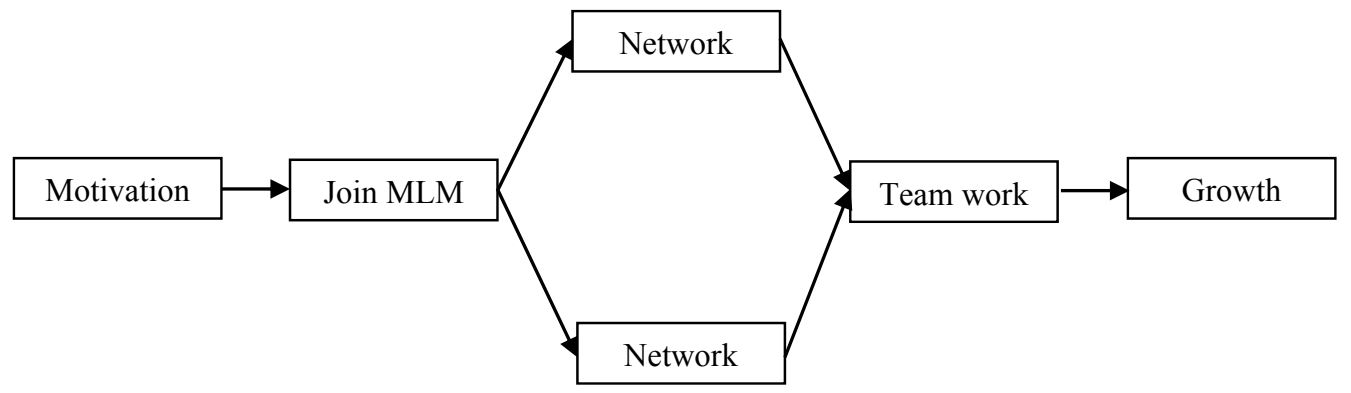

Fig. 5. Impact of Motivation

In this study, we aimed to explore the various motivational factors that influence the people to join MLM. We proposed a confirmatory factor analysis model and testing construct covariance for better understanding of motivational factors in MLM system.

\section{Research methodology}

This study investigated the factors that motivated the respondents to join MLM business. The 26 item semi-structured questionnaire was developed to rate them on 5-point Likert scale and sent to 23 MLM experts for pre-pilot survey. Then it was improved on the basis of their recommendations and sent for pilot survey. The results of pilot survey did not support the level of acceptance of Eigen and communality values of two items i.e. support system and extra skills. Therefore, we removed these two items form questionnaire after discussion with experts. Finally, the large scale survey was done on 24item, 5 points Likert scale $(1=$ strongly disagree to $5=$ strongly agree $)$. The 382 questionnaires were sent to distributors working in various MLM companies irrespective of their demographic features within the region of Punjab, Chandigarh and Haryana. Thus, respondents from all walks of life were ensured. The respondents answered a 2-Part questionnaire. Part A-Contained questions on the respondents' demographic profile and Part-B was about the reasons for joining MLM. Finally, the 337 questionnaires were returned that demonstrate the $88.21 \%$ return rate. But we found 21 unengaged responses and did not digitize them in SPSS. Finally, the total 316responses were used for data analysis. The principal component factor analysis with varimax rotation technique was used to group the same items in one construct.

\section{Results and discussion}

A factor analysis was performed to identify the motivational factors that allured the respondents to join MLM business. The results obtained (.912) value of Kaiser-Mayer-Olkin (KMO) and Chi square (8566.11) and $\mathrm{P}$ value is $(0.000)$. The social responsibility has a maximum variance of $(22.904 \%)$, self development has a variance of $(21.887 \%)$ followed by personal freedom and working lifestyle with 
variance of $(20.992 \%)$ and $(14.993 \%)$ respectively. The cumulative percentage of variance is 22.904 $\%, 44.791 \%, 65.783 \%$ and $80.776 \%$ respectively.

Table 3

Scale Statistics

\begin{tabular}{|c|c|c|c|c|}
\hline \multirow[b]{2}{*}{ Variables } & \multirow[b]{2}{*}{ Mean } & \multirow[b]{2}{*}{$\begin{array}{c}\text { Total Corrected } \\
\text { items }\end{array}$} & \multicolumn{2}{|c|}{ Communality } \\
\hline & & & Initial & Final \\
\hline Contribution & 2.2215 & .800 & 1.000 & .736 \\
\hline Learning & 2.0886 & .911 & 1.000 & .884 \\
\hline Extra Money & 4.5000 & .841 & 1.000 & .811 \\
\hline Challenged & 3.2627 & .954 & 1.000 & .946 \\
\hline CSR & 2.1139 & .955 & 1.000 & .944 \\
\hline Innovative & 2.123 & .927 & 1.000 & .907 \\
\hline Work Anytime & 4.5411 & .902 & 1.000 & .882 \\
\hline Work Anywhere & 4.4778 & .814 & 1.000 & .771 \\
\hline Accomplishment & 3.7880 & .710 & 1.000 & .634 \\
\hline Build Rapport & 3.9051 & .946 & 1.000 & .933 \\
\hline Lifestyle & 2.2658 & .874 & 1.000 & .850 \\
\hline Leadership & 3.9051 & .840 & 1.000 & .807 \\
\hline Fun & 2.2658 & .840 & 1.000 & .793 \\
\hline Financial Security & 3.3829 & .822 & 1.000 & .768 \\
\hline Locations & 3.3228 & .948 & 1.000 & .936 \\
\hline Be Own Boss & 3.8323 & .860 & 1.000 & .842 \\
\hline Recognition & 3.3544 & .777 & 1.000 & .710 \\
\hline Company Image & 3.7627 & .778 & 1.000 & .731 \\
\hline Low Investment & 4.4715 & .709 & 1.000 & .628 \\
\hline Easy Entry & 4.4873 & .797 & 1.000 & .747 \\
\hline Compensation Plan & 3.8956 & .745 & 1.000 & .686 \\
\hline No Sale Target & 3.3608 & .839 & 1.000 & .792 \\
\hline Product Quality & 4.5222 & .788 & 1.000 & .745 \\
\hline Company Policy & 3.2974 & .925 & 1.000 & .906 \\
\hline Chi square $=8566.11$ & $\mathrm{Df}==276$ & Variables $=24$ & Number $=316$ & Alpha $=.841$ \\
\hline Variance $=.772$ & Item mean $=3.54$ & & & \\
\hline
\end{tabular}

Table 4

Factor Analysis Results

\begin{tabular}{|c|c|c|c|c|}
\hline \multirow{2}{*}{ Variables } & \multicolumn{4}{|c|}{ Factors } \\
\hline & Social Responsibility & $\begin{array}{c}\text { Self } \\
\text { Development }\end{array}$ & $\begin{array}{l}\text { Personal } \\
\text { Freedom }\end{array}$ & $\begin{array}{l}\text { Working } \\
\text { Lifestyle }\end{array}$ \\
\hline CSR & .970 & & & \\
\hline Build Rapport & .965 & & & \\
\hline Innovative & .951 & & & \\
\hline Learning & .940 & & & \\
\hline Fun & .889 & & & \\
\hline Contribution & .885 & & & \\
\hline Challenged & & .970 & & \\
\hline Locations & & .965 & & \\
\hline Company Policy & & .950 & & \\
\hline No Sale Target & & .884 & & \\
\hline Financial Security & & .875 & & \\
\hline Recognition & & .834 & & \\
\hline Work Anytime & & & .937 & \\
\hline Extra Money & & & .896 & \\
\hline Work Anywhere & & & .863 & \\
\hline Product Quality & & & .857 & \\
\hline Easy Entry & & & .847 & \\
\hline Low Investment & & & .792 & \\
\hline Lifestyle & & & & .917 \\
\hline Be Own Boss & & & & .906 \\
\hline Leadership & & & & .888 \\
\hline Company Image & & & & .848 \\
\hline Compensation Plan & & & & .812 \\
\hline Accomplishment & & & & .788 \\
\hline Eigen Values & 5.497 & 4.873 & 4.654 & 3.598 \\
\hline$\%$ Of Variance & 22.904 & 21.887 & 20.992 & 14.993 \\
\hline Cumulative \% Of Variance & 22.904 & 44.791 & 65.783 & 80.776 \\
\hline Alpha & .968 & .961 & .935 & .845 \\
\hline Factor mean & 2.15 & 3.33 & 4.49 & 3.82 \\
\hline
\end{tabular}


Table 4 shows the loading of all 24 variables. All the 4 factors have good loadings and comprised the same number (6) of variables. The obtained values in this study are following:Cronbach alpha value $=$ $>0.841$, Item-to-total correlation $=.955$ to .709 and Inter-item-correlation $=.967$ to .537 .

Table 5

Result of Factor Analysis

\begin{tabular}{|c|c|c|c|c|c|c|}
\hline Factor & $\begin{array}{c}\text { Total Covered } \\
\text { Variables }\end{array}$ & $\begin{array}{c}\text { Factor Loading } \\
\text { Range }\end{array}$ & $\begin{array}{c}\text { Inter-Item } \\
\text { Correlation Range }\end{array}$ & $\begin{array}{c}\text { Item-To-Total } \\
\text { Correlation Range }\end{array}$ & $\begin{array}{l}\text { Explained } \\
\text { Variance }\end{array}$ & Eigen Value \\
\hline Social Responsibility & 6 & .970 to .885 & .942 to .687 & .955 to .800 & 22.904 & 5.497 \\
\hline Self-Development & 6 & .970 to .834 & .967 to .661 & .955 to .777 & 21.887 & 5.253 \\
\hline Personal Freedom & 6 & .937 to .792 & .835 to .599 & .902 to .709 & 20.992 & 5.038 \\
\hline Working Lifestyle & 6 & .917 to .788 & .842 to .537 & .874 to .710 & 14.993 & 3.598 \\
\hline
\end{tabular}

\section{Confirmatory model results}

The proposed confirmatory factor analysis model is shown in Fig. 6. The personal freedom construct loadings for variables are given as: low investment (.73), work any time (.94), extra money (.88), work anywhere (.85), product quality (.82), and easy entry (.82). This construct's obtained mean (4.49) shows that the variables under this construct have the maximum level of contribution in motivating respondents to join MLM. The respondents have desire to call their shots with their own style. The Study also revealed that they can join MLM without any hurdle and they can earn extra money by making low investment. The majority of the respondents rated MLM products of high quality. The followings are the variables involved in construct of working lifestyle and their loadings are shown as following: accomplishment (.72), compensation plan (.76), company image (.78), leadership (.90), be own boss (.91), lifestyle (.92) and the construct mean (3.82) revealed that be own boss and compensation policy are key variables. The majority of the respondents claim that they join MLM because of these variables. Personal accomplishments, leadership quality and to improve lifestyle play an important role to motivate respondents. Brand name of the company is also one of the important motivational variables that attract respondents towards the company.Fig. 6 Shows that self development has 6 variables that are depicted with their loadings as following: challenged (.99), location (.98), company policy (.96), no sales target (.86), financial security (.81) and recognition (.76). The construct mean value (3.33) shows, there is mix response regarding above variables. There is covariance of (.39) between e11 and e12 in this construct. MLM companie's challenging tasks, policies regarding recognition and sales target affect some respondent's perception to join the MLM system. This business system also provides opportunities for its members to work at exotic locations which create willingness to join this commerce activity. As a financial security concerned, MLM is no exception because financial security has been always a reason for doing any business. But respondents are perplexed to consider financial security as a motivational variable.

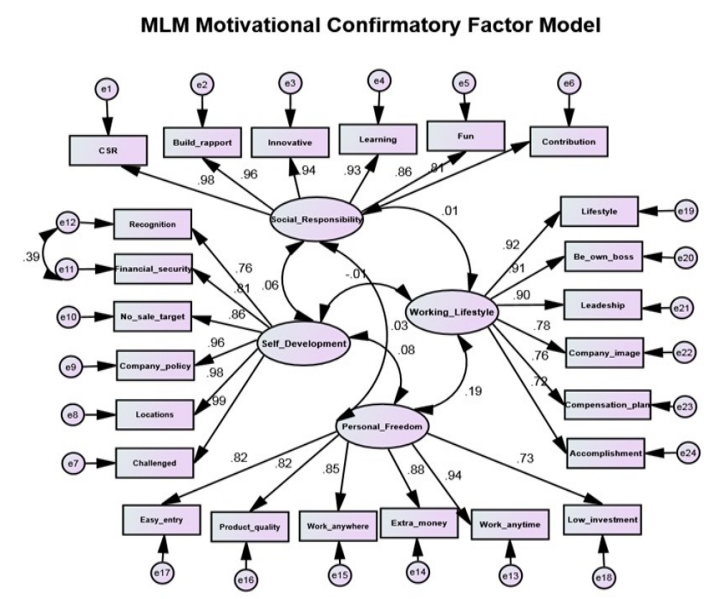

Fig. 6. MLM Motivational Confirmatory Factor Model 
Social responsibility construct has 6 variables with total construct mean of 2.15 . The loadings of this construct are: CSR (.98), build rapport (.96), innovative (.94), learning (.93), fun (.86) and contribution (.81).This results evinced, that these variables do not motivate respondents to join MLM business.

\section{Model fit}

The Tables from 6 to 10 show the obtained model fit values. Here, we have obtained CMIN/DF value (.986), P value (.000), CFI (.986), GFI (.901), RMSEA (.039) and PCLOSE (.984). This indicates that the purposed model absolutely fits for motivational factors that affect joining decision.

\section{Table 6}

\section{CMIN}

\begin{tabular}{lrrrrr}
\hline Model & NPAR & CMIN & DF & P & CMIN/DF \\
\hline Default model & 79 & 364.854 & 245 & .000 & 1.489 \\
Saturated model & 324 & .000 & 0 & & \\
Independence model & 48 & 8813.261 & 276 & .000 & 31.932 \\
\hline
\end{tabular}

Table 7

RMR, GFI

\begin{tabular}{lrrrr}
\hline Model & RMR & GFI & AGFI & PGFI \\
\hline Default model & .076 & .901 & .879 & .739 \\
Saturated model & .000 & 1.000 & & \\
Independence model & .517 & .250 & .185 & .230 \\
\hline
\end{tabular}

\section{Table 8}

Baseline Comparisons

\begin{tabular}{lrrrrr}
\hline Model & $\begin{array}{r}\text { NFI } \\
\text { Delta1 }\end{array}$ & $\begin{array}{r}\text { RFI } \\
\text { rho1 }\end{array}$ & $\begin{array}{r}\text { IFI } \\
\text { Delta2 }\end{array}$ & $\begin{array}{r}\text { TLI } \\
\text { rho2 }\end{array}$ & $\begin{array}{r}\text { CFI } \\
\hline \text { Default model }\end{array}$ \\
Saturated model & .959 & .953 & .986 & .984 & .986 \\
Independence model & 1.000 & & 1.000 & .000 & .000 \\
\hline
\end{tabular}

\section{Table 9}

Parsimony-Adjusted Measures

\begin{tabular}{lrrr}
\hline Model & PRATIO & PNFI & PCFI \\
\hline Default model & .888 & .851 & .875 \\
Saturated model & .000 & .000 & .000 \\
Independence model & 1.000 & .000 & .000 \\
\hline
\end{tabular}

\section{Table 10}

RMSEA

\begin{tabular}{lrrrr}
\hline Model & RMSEA & LO 90 & HI 90 & PCLOSE \\
\hline Default model & .039 & .031 & .048 & .984 \\
Independence model & .313 & .308 & .319 & .000 \\
\hline
\end{tabular}

It is highly necessary to establish reliability as well as validity for confirmatory factor analysis. The absence of validity and reliability makes model useless. Hair et al. (2010) proposed some parameters of model reliability and validity is hereunder: shown in Table 11.

\section{Model validity}


Table 11 shows that there is no validity concerns. All required values of Composite Reliability (CR), Average Variance Extracted (AVE), Maximum Shared Variance (MSV) and Average Share Variance ASV are obtained. Thus, the proposed model is absolutely valid for MLM business.

\section{Table 11}

Model validity

\begin{tabular}{lllll}
\hline Construct & CR & AVE & MSV & ASV \\
\hline Self Development & 0.959 & 0.797 & 0.006 & 0.003 \\
Social Responsibility & 0.967 & 0.832 & 0.003 & 0.002 \\
Working Lifestyle & 0.928 & 0.685 & 0.034 & 0.012 \\
Personal Freedom & 0.935 & 0.706 & 0.036 & 0.015 \\
\hline
\end{tabular}

\section{Conclusion and recommendations}

In this study, we developed a motivational model for MLM system. The obtained results demonstrated that product quality, easy entry, low investment, extra money, work anytime and anywhere are the most effective variables that persuade people to join MLM. Leadership, personal accomplishment, company image, be own boss are also some key variables that attracts people towards MLM. Here, the social responsibility factor does not contribute in motivating people to join MLM. On the other hand, self development factor obtained a mean score of 3.33 which reveals the mix response of the respondents towards the variables comes under self development construct.

In addition, the motivational confirmatory model shows that all factors are independent because there is no correlation among them. The results of this study have been empirically tested and validated.

The findings suggest that MLM companies should focus on providing recognition to their loyal and hardworking distributors. MLM should formulate the policies in such a way that each member or distributor feels financially secure and comfortable to work.

The proposed model will help MLM companies to formulate better strategies to overcome turnover problems faced by distributors and ensure their commitment towards work. Further, it yields high productivity in organization. On other hand, Legitimate MLM companies are required to make their policies more transparent and conduct seminars to create awareness amongst people regarding the business structure.

In this research, the target population was the only MLM companies' distributors in India. This study would have been more extensive and beneficial if it had also included customers of MLM companies in India. A future research can be carried out on MLM product attributes that allure customers to purchase the products and join the business.

\section{Acknowledgement}

We would like to thank the top level executives of MLM companies in India for their kind cooperation and support in conducting this research.

\section{References}

Agbo, M. (2013). A paradox about the MLM. Available at: http://papers.ssrn.com/sol3/papers.cfm?abstract_id=2345287.

Akiny, A.R. (2008). Benefits and challenges of MLM in Kenya: A case of golden neolifediamite international distributors in Nairobi, Kenya. School of Business: University of Nairobi.

Attri, R. (2011). A study of consumer perceptions of the products sold through multi level marketing. Management Research Journal(Prabandhan\&Taqniki),39(83), 97-103. 
Bhardwa, S.N. \&Bordoloi, A. (2014). A study on network marketing and its present scenario with special reference to Guwahati city.Journal of Indian Streams Research, 4(8), 33-45.

Buschgens, T., Baush, A. \&Balkin, D.V. (2013).Organizing for radical innovation- a multilevel behavioural approach. The Journal of High Technology Management Research, 24(2), 138-152.

Chang, A. \& Tseng, C.N. (2005).Building customer capital through relationship marketing activities.Journal of Intellectual Capital, 6(2), 253-266.

Chen, D.F.R. \&Jeng, L.J. (2012). A study of consumer who buy from the MLM channel in Taiwan. Available at: http://www.cadsm.org/dsrc-cn/research/English/English\%20Papers/009.pdf.

Cheung, Pui-lin\& Josephine (1993). MLM in Hong Kong: a unique direct marketing strategy. The University of Hong Kong.

Choudhary, R. (2013). MLM for socio-economic development.International Journal of Review, Surveys and Research, 2(1), 45-55.

Constantin, C. (2009).Multilevel marketing-a tool of relationship marketing. Bulletin of the Transilvania University of Braso.

Coughlan, A.T. \&Grayson, K.(1998). Network marketing organizations: compensation plans, retail network growth, and profitability. International Journal of Research in Marketing, 15(5), 401-426.

Dai, F., Wang, K.Y. \& Stephen, T.T. (2011). Chinese immigrant in network marketing business in western host country.International Journal Review, 20(6),656-669.

Dominique, X. (1993). The direct selling revolution: Understanding the Growth of the Amway Corporation. Blackwell Publishing.

Durmaz, Y. (2014). The impact of psychological factors on consumer buying behaviour and an empirical application in Turkey. Asian Social Science, 10(6), 45-60.

Fuji, H. \&Taji, N. (2013). The mechanism of promoting distributor's activity in MLM. Department of Management and Information Science, Meisei University, Tokyo, Japan.

Goncalves, R.P. (2008). Consumer behaviour: product characterstics and quality perception. University Autonoma de Barcelona.

Gummessonm, Evert (1994). Making relationship marketing operational.Journal of Small Business Management, 5(5), 5-20.

Ismail, Z., Masood, S. \&Tawab, M.T. (2012). Factors affecting consumer preference of international brands over local brands. International Proceedings of Economics Development and Research, 31(6), 53-67.

Joshi, S.V. (2014). Perception that motivate purchase. International Journal of Engineering,Business Enterprise Application, 1(7),78-82.

Jumpon, N.L, Smaksman, K., Suwannasatit, S., Phomsiri, S. \&Lertridecle, S. (2013). Factors motivating direct selling agents to become successful in MLM. College of Innovation Management, Rajamangala, University of Technology, Thailand.

Katarzyna, M. (2012). Motivation in organizations operating on the basis of a MLM system: how do people motivate themselves? School of Business, National College of Ireland.

Keun, N. G. (2004). Participation in network marketing companies, the motivational factors that influence the part time distributors in kuching Sarawak. Faculty of Economics and Business, University of Malaysia, Sarawak.

Koroth, A.A. (2013). The influence of demographic on the perception level of MLM distributors. The International Journal of Management, 2(1), 1-15.

Koroth, A.A. \&Sarada, A.K. (2012). Significance of relationship in multi- level marketing and its effect on business outcome. Journal of Business and Management, 3(6), 26-36.

Kustin, A.R. \& Jones, A.R. (1995). A study of direct selling perceptions in Australia. International Marketing Review, 12(6),60-68.

Legara, E.F., Monterila, C., Juanico, D.E., Palma. M.L. \&Salom, C. (2008). Earning potential in multilevel marketing enterprises. Physica A: A statistical Mechanics and Its Applications, 387(19), 4889-4895.

Malik, P. (2012).Direct selling: collective versus individualistic.Available at: http://papers.ssrn.com/sol3/papers.cfm?abstract_id=2147685 
Marsh, J. (2004). Technology of persuasion in mlm or network marketing companies. Available at: http://www.energygrid.com/money/2004/03jm-mlm.html

Nat, P.J.V. \& Wicked, W. (2002). Marketing fraud: an approach for differentiating multilevel marketing from pyramid schemes. Journal of Public Policy \& Marketing,21(1), 139.

Nga, J.K.H. \&Mun, S.W. (2010). The influence of MLM companies and agent attributes on the willingness to undertake multilevel marketing as a career option among youth. Journal of Research in Interactive Marketing,5(1),50-70.

Oksanes, E.(1999). Structure and characterstics of network marketing business. Helsinki School of Economics and Business Administration, Helsinki.

Palmatier, R.W., Scheer, L., Houston, M.B., Evans, K.P. \&Gopalkrishna, S. (2007). Use of relationship marketing programs in building customer-salesperson and customer firm relationships: differential influence on financial outcomes. International Journal of Research in Marketing, 24(3), 210-233.

Pareja,S. (2008). Sales gone wild: Will the ftc's business opportunity rule put an end to pyramid marketing schemes. McGeorge Law Review,39, 83.

Parvin,M.M., \&Kabir, M.M. (2011). Factors affecting employees job satisfaction on pharmaceutical sector. Australian Journal of Business and Management Research, 1(9), 113-123.

Phan, P.R. (2012). Consumer attitudes towards corporate image of direct sellingcompanies in Thailand. International Journal of E-Education, E-Business, E-Management and E-Learning, 2(4), 68-82.

Phuong, L.E. (2013). The effects of leadership behaviour on organizational commitment through the satisfaction of the multilevel marketing distributors- A study in Ho Chi Minh city. Vietnam National University-Ho chi Minh City, Vietnam.

Qasim, S. \&Sayeed, F.C. (2012). Exploring factors affecting employees job satisfaction at work. Journal of Management and Social Science, 8(1), 21-39.

Radmand, L. \&Mukhtaram, S. (2013). Determinants and outcomes of strategic orientation: empirical evidence from multilevel marketing industry of Malaysia. Business and Management Quarterly Review,4(1), 1-21.

Rani, R. \& Kumar, N. (2013.)Multilevel marketing versus pyramid schemes. International Monthly Refereed Journal of Research in Management and Technology, 2, 13-23.

Shirani, A., Danae, H. \&Shirvani, A. (2014). A study on different factors influencing customer satisfaction on industrial market. Management Science Letters,4(4), 139-144.

Singh, R., Sandhu, H.S., Metri, B.A. \& Kaur, R. (2013). Understanding organized retail supply chain environment: A confirmatory factor model. International Journal of Operations Research and Information System, 1(2), 0377.

Sparks, J.R. \& Schenk, J.A. (2001). Explaining the effects of transformational leadership.Journal of Organizational Behaviour, 22(8), 849-869.

Spire,(2011). Will multilevel marketing become a game - changer in emerging markets?". Spire Research and Consulting Pt. Ltd.

Wang, S. \& Cheng, S.T. (1998). Success factors for direct selling business. International Journal of Research in Marketing, 15, 401-426.

Yunus, R.B.M. (2006). User perception on online mlm. Available at:http://eprints.uitm.edu.my/2027/1/RUSLINA_BINTI_MOHD._YUNUS_06_s24.pdf

Zamanian, A.H. (1966). Multilevel networks in less developed countries. Journal of Applied Mathematics and Computation,18(3), 185-210. 